\title{
MODELING OF CHEMICAL WEAR IN FERROUS ALLOYS/ SILICON NITRIDE CONTACTS DURING HIGH SPEED CUTTING
}

\author{
R. F. SILVA', F. J. OLIVEIRA ${ }^{\prime}$, F. P. CASTRO ${ }^{2}$ and J. M. VIEIRA \\ Dep. Eng. Cerâmica e do Vidro, Universidade de Aveiro, 3810 Aveiro, Portugal and ${ }^{2}$ Dep. Eng. \\ Mecânica, Universidade do Minho, 4810 Guimarães, Portugal
}

\begin{abstract}
The wear resistance of $\mathrm{Si}_{3} \mathrm{~N}_{4}$ in machining of iron alloys can be surprisingly low due to chemical affinity for dissolution in the metal. This limits the use of $\mathrm{Si}_{3} \mathrm{~N}_{4}$ inserts in high speed machining of steels, while $\mathrm{Si}_{3} \mathrm{~N}_{4}$ retains the best performance of all cutting materials in turning of grey cast iron, a different ferrous alloy. The chemical wear of several ceramics has been investigated on the basis of dissolution in pure iron by Kramer and Suh. Nevertheless, the influence of alloy elements was not studied. In the present work, solid solution thermodynamics is applied to predict chemical wear of $\mathrm{Si}_{3} \mathrm{~N}_{4}$ by setting the influence of interaction coefficients of the alloy elements in the Henrian activity of $\mathrm{Si}$ and $\mathrm{N}$ in austenite. The model predicts the relative order of magnitude of the crater wear of $\mathrm{Si}_{3} \mathrm{~N}_{4}$ inserts in machining of tool steels, carbon steels and grey cast iron. (C) 1998 Acta Metallurgica Inc.
\end{abstract}

\section{INTRODUCTION}

In the field of cutting tools it is most relevant to study processes of chemical or diffusion wear of $\mathrm{Si}_{3} \mathrm{~N}_{4}$ because of the intimate and strong contact between the ceramic insert and the metal workpiece at high temperatures. Tool degradation results from a combination of mechanical and chemical processes, but in high speed machining of continuous chip forming workpiece materials like the steels, the dominant wear mode is chemical $[1,2]$. Even when turning nickel based alloys, $\mathrm{Si}_{3} \mathrm{~N}_{4}$ has only good performance at low speeds showing a quasi-exponential growth of the wear rates with increasing cutting speeds due to diffusion wear [3]. Interdiffusion between elements of the workpiece and tool, solution of tool material and formation of new phases by chemical reactions at the metal/ceramic interface leading to severe crater wear have been reported [1,4-8]. Interdiffusion weakens the material structure allowing fast disruption of the tool surface [5]. Tonshoff and Bartsch [4] detected components of the ceramic tool material in the secondary flow zone of the metal chip. Depletion of tool elements such as Si and $\mathrm{Y}$ at the flank face of the tool confirms that the ceramic dissolves into the hot metal [9].

Thermodynamic calculations addressing the chemical stability of $\mathrm{Si}_{3} \mathrm{~N}_{4}$ and other cutting tool ceramics in machining of iron alloys were performed by Kramer et al. $[10,11]$. The solubility of the tool was calculated from the free energy of formation of the ceramic material and from the relative partial molar excess free energies of solution of its components in the pure metal. Data clearly showed that wear of oxide tools is not controlled by solubility whereas such wear mode dominates carbide tools. Aronsson [12], in comparative testing of silicon nitride and alumina based cutting tools attributes to chemical inertness the superior crater wear resistance of alumina. However, under conditions of high metal removal rate where toughness and hardness are definitively required, silicon nitride inserts perform better than some alumina tools [13]. Although the thermodynamic approach of Kramer et al. has ranked the cutting tool materials in order of the expected reactivity, it has some limitations. It is restricted to the equilibrium with pure iron by not considering the effects of alloying elements. Other authors $[1,7,14]$ have explored Kramer's model but some chemical parameters used for the thermodynamic calculations were taken constant over a broad range of temperatures and concentration of alloying elements which is a rather crude approximation. The influence of steel composition in ceramic dissolution was recently investigated by static diffusion couples as a way of predicting chemical wear $[7,15]$. The authors used the molecular nitrogen solubility and not the actual $\mathrm{Si}_{3} \mathrm{~N}_{4}$ solubility in steels which can lead to large discrepancies in the final results.

In the present work a model to determine the $\mathrm{Si}_{3} \mathrm{~N}_{4}$ solubility in different iron alloys is developed considering more realistic assumptions for the equilibrium conditions. Experimental values of the solubility products in the solid iron phases and interaction coefficients of all solute atoms were used to calculate the $\mathrm{Si}$ and $\mathrm{N}$ concentrations in the metal in equilibrium with $\mathrm{Si}_{3} \mathrm{~N}_{4}$. Even conceding that the present thermodynamic model does not take into account reaction kinetics, it gives a realistic measure of the potential for chemical reaction, 
the correlation between $\mathrm{Si}_{3} \mathrm{~N}_{4}$ solubility and the crater wear rate of $\mathrm{Si}_{3} \mathrm{~N}_{4}$ based cutting tools being further investigated.

\section{THERMODYNAMIC CALCULATIONS OF $\mathrm{Si}_{3} \mathrm{~N}_{4}$ SOLUBILITY IN IRON ALLOYS}

Iron alloys are multicomponent solid solutions in Fe where alloying elements strongly interact with one another. The solubility of $\mathrm{Si}_{3} \mathrm{~N}_{4}$ in distinct iron alloys will be calculated at a reference temperature of $1000^{\circ} \mathrm{C}$, which is representative of the conditions developed at the contact between the metal chip and the rake face of the ceramic tool during high speed cutting. $\mathrm{Fe}$ and $\mathrm{Si}_{3} \mathrm{~N}_{4}$ react at $950^{\circ} \mathrm{C}$ and above [16]. Equilibrium within the $\gamma-\mathrm{Fe}$ phase is considered for thermodynamic evaluation of $\mathrm{Si}_{3} \mathrm{~N}_{4}$ solubility in solid iron. Cast iron, carbon and chromium alloyed steels represent broad classes of iron alloys that have been investigated in relation to the benefits of high speed machining with ceramic cutting inserts [1-9]. In the analysis of crossed chemical interactions, $\mathrm{Cr}-\mathrm{N}$ interaction competes with the dissolution of $\mathrm{Si}_{3} \mathrm{~N}_{4}$ and molccular $\mathrm{N}_{2}$ in austenitic iron. The chemical equilibria for phase compatibility in the $\mathrm{Si}_{3} \mathrm{~N}_{4}-\mathrm{CrN}-(\gamma-\mathrm{Fe})_{\mathrm{ss}}$ system are given in Table 1. By convenience, the activities of the alloying elements and $\mathrm{Si}$ and $\mathrm{N}$ from the $\mathrm{Si}_{3} \mathrm{~N}_{4}$ ceramic tool in iron, will bc defincd on a weight pcrcent basis using Henry's law for dilute systems [17]:

$$
\log \left(h_{i}\right)=\log [\% i]+\sum_{j} e_{i}^{j}[\% j]
$$

where $h_{i}$ is the Henrian activity of the $i$ element, $[\% i]$ and $[\%]$ are the concentrations in weight percent of the $i$ and $j$ elements dissolved in the alloy. The changes of chemical activity of those elements in the $\gamma$-Fe solid solution is expressed by the first order interaction coefficients $e_{j}^{i}$. Information on $e_{j}^{i}$ values, namely in $\gamma-\mathrm{Fe}$, is scarce compared to data for liquid iron. However, as described below, values of coefficients $e_{j}^{i}$ were calculated from analysis of published phase diagrams or were estimated from numerical data available for liquid iron and for $\alpha$ Fe. In some cases transposed $e_{i}^{j}$ values were assessed from the corresponding published values of $e_{j}^{i}$ parameters in $\gamma-\mathrm{Fe}$, by applying a procedure given by Lupis [18]:

$$
e_{i}^{j}=\frac{M_{i}}{M_{j}} e_{j}^{i}+\frac{1}{230} \frac{M_{j}-M_{i}}{M_{j}}
$$

where $M$ is the atomic weight of the element. The

Table 1. Chemical equilibria in $\mathrm{Si}_{3} \mathrm{~N}_{4} / \mathrm{Fe}$-alloys interactions

\begin{tabular}{ccc}
\hline Chemical equilibrium & Equilibrium constant & Equation \\
\hline $\mathrm{Si}_{3} \mathrm{~N}_{4}=3 \mathrm{Si}^{\mathrm{a}}+4 N$ & $K_{\mathrm{I}}$ & $(3)$ \\
$\mathrm{Cr}+N=\mathrm{CrN}$ & $K_{\mathrm{II}}$ & $(4)$ \\
$\mathrm{Si}_{3} \mathrm{~N}_{4}+4 \mathrm{Cr}=3 \mathrm{Si}+4 \mathrm{CrN}$ & $K_{\mathrm{III}}$ & $(5)$ \\
$1 / 2 \mathrm{~N}_{2}=N$ & $K_{\mathrm{IV}}$ & $(6)$ \\
\hline
\end{tabular}

${ }^{\mathrm{a}}$ The dissolved species in austenitic iron appear italic.
Table 2. Dependence of first order interaction coefficients on temperature

\begin{tabular}{cccc}
\hline \multicolumn{4}{c}{$e_{1}^{j}(T)=a+b / T$} \\
\hline$e_{i}^{j}$ & $a$ & $b$ & Ref. \\
\hline$e_{S i}^{S i}$ & -0.135 & 364 & {$[16,19]$} \\
$e_{N}^{S N}$ & -0.110 & 274 & {$[16]$} \\
$e_{N}^{N}$ & - & 109 & {$[16]$} \\
$e_{\mathrm{C}}^{S i}$ & - & 128 & {$[16]$} \\
\hline
\end{tabular}

complete set of interaction coefficients needed for the calculation of solubility in the different iron alloys was calculated as described in the following.

\subsection{First order interaction coefficients $e_{i}^{j}$ in $\gamma$-iron}

A summary of known values of first order interaction coefficients as a function of temperature is given in Table 2. $e_{\mathrm{Si}}^{\mathrm{Si}_{\mathrm{i}}}$ for $\gamma-\mathrm{Fe}$ was considered the same as that for $\alpha$-Fe [16] due to the narrow twophase transition between the $\gamma$-loop and $\alpha$ region in the $\mathrm{Fe}-\mathrm{Si}$ phase diagram [19]. $e_{\mathrm{N}}^{\mathrm{Si}}, e_{\mathrm{N}}^{\mathbf{N}}$ and $e_{\mathrm{C}}^{\mathrm{Si}}$ were derived by Kunze et al. [16]. The Raoultian interaction coefficient in $\gamma$-Fe, $\varepsilon_{\mathrm{Si}}^{\mathrm{Cr}}=0.05$ [20] was converted to the Henrian interaction coefficients, giving $e_{\mathrm{Si}}^{\mathrm{Cr}} \approx 0$ and $e_{\mathrm{Cr}}^{\mathrm{Si}} \approx 0$. $e_{\mathrm{Cr}}^{\mathrm{C}}=-0.051$ and $e_{\mathrm{C}}^{\mathrm{C}}=0.18$ were estimated from the Raoultian interaction coefficients at $1273 \mathrm{~K}, \varepsilon_{\mathrm{C}}^{\mathrm{Cr}}=-10.9$ [18] and $\varepsilon_{\mathrm{C}}^{C}=8.7$ [18], respectively. No value of $e_{\mathrm{Cr}}^{\mathrm{Cr}}$ in $\gamma$-Fe was found in the literature, but self interaction coefficients are usually very small as it is the case of $e_{\mathrm{Cr}}^{\mathrm{Cr}}$ in liquid iron $(-0.0003)$ [21]. So this value is approached to zero.

Kagawa et al. [22] measured the solubility of nitrogen in austenite in equilibrium with gaseous $\mathrm{N}_{2}$ at $1 \mathrm{~atm}$, in a $\mathrm{Fe}-\mathrm{C}-\mathrm{N}$ alloy, equation (6) in Table 2. By applying equation (1) the expression of the equilibrium constant $K_{\text {IV }}$ for equation (6) can be rearranged to:

$$
\log [\% \mathrm{~N}]+0.086[\% \mathrm{~N}]=\log K_{\mathrm{IV}}-e_{\mathrm{N}}^{\mathrm{C}}[\% \mathrm{C}]
$$

$e_{\mathrm{N}}^{\mathrm{N}}$ being given in Table 3 . The first term of this equation is plotted against $[\% \mathrm{C}]$ in Fig. 1 taking the values of $[\% \mathrm{~N}]$ and $[\% \mathrm{C}]$ at the solubility limit in austenite [22]. Linear regression analysis gives $e_{\mathrm{N}}^{\mathrm{C}}=0.075$, the transpose $e_{\mathrm{C}}^{\mathrm{N}}$ given by equation (2).

The interaction coefficients for the different alloys studied in the present paper are summarized in Table 3 for the temperature of $1273 \mathrm{~K}$. Equation (2) was applied to calculate $e_{\mathrm{Si}}^{\mathrm{N}}, e_{\mathrm{Si}}^{\mathrm{C}}$ as the transpose of $e_{\mathrm{N}}^{\mathrm{Si}}$ and $e_{\mathrm{C}}^{\mathrm{Si}}$, respectively. The value of $e_{\mathrm{Cr}}^{\mathrm{N}}$ is calcu-

Table 3. First order interaction coefficients $e_{i}^{j}$ in $\gamma$-Fe at $1273 \mathrm{~K}$

\begin{tabular}{lllll}
\hline$i$ & \multicolumn{5}{c}{$j$} \\
\hline $\mathrm{Si}$ & $\mathrm{N}$ & $\mathrm{C}$ & $\mathrm{Cr}$ \\
\hline $\mathrm{Si}$ & 0.15 & 0.21 & 0.23 & 0 \\
$\mathrm{~N}$ & 0.11 & 0.086 & 0.075 & -0.10 \\
$\mathrm{C}$ & 0.10 & 0.065 & 0.18 & -0.051 \\
$\mathrm{Cr}$ & 0 & -0.40 & -0.24 & 0 \\
\hline
\end{tabular}




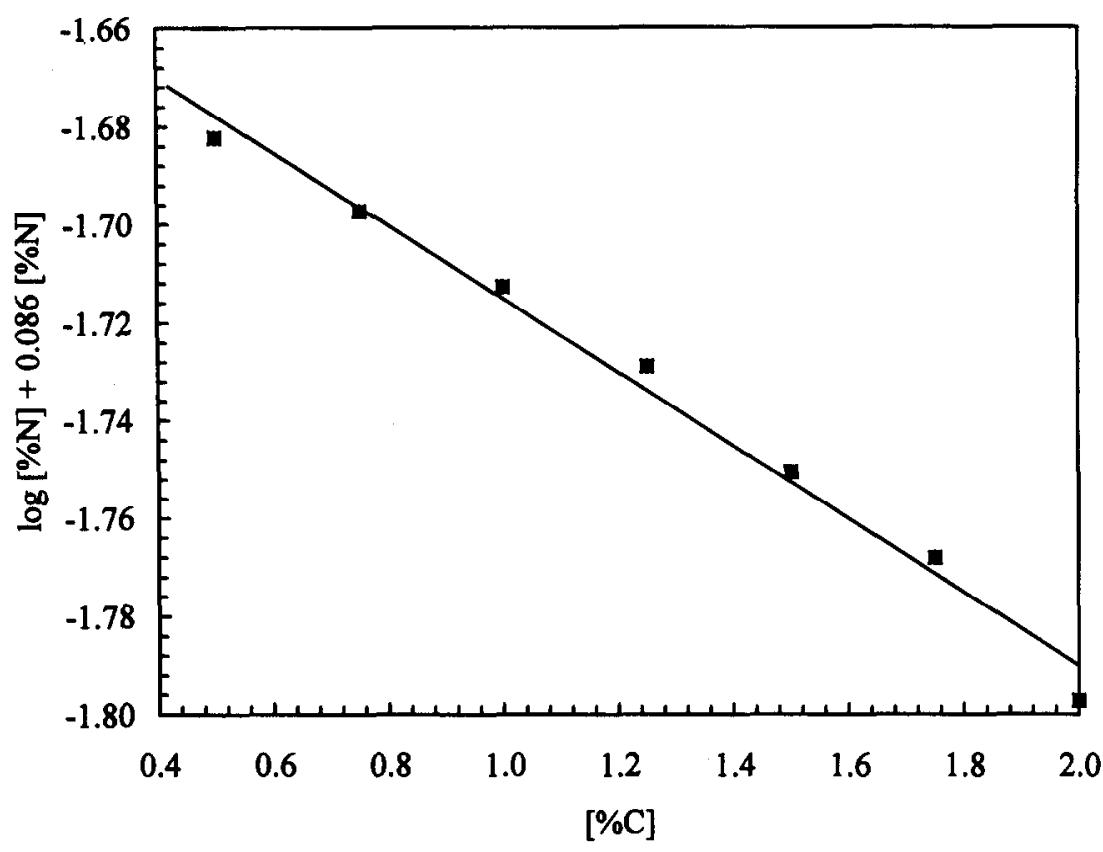

Fig. 1. Graphical determination of $e_{\mathrm{N}}^{\mathrm{C}}$ by equation (7).

lated in the section on chromium alloyed steels, below.

\subsection{Dissolution of $\mathrm{Si}_{3} N_{4}$ in pure iron}

The concentration of $\mathrm{Si}$ and $\mathrm{N}$ in pure $\gamma$-iron at $1000^{\circ} \mathrm{C}$ in equilibrium with silicon nitride is calculated from data of the work of Kunze et al. [16]. The equations for nitrogen concentration in austenitic and ferritic iron and the solubility product of $\mathrm{Si}_{3} \mathrm{~N}_{4}$ in ferritic iron are summarized in Table 4. Equations (8)-(10) can be rearranged to the form of equation (11):

$$
\begin{aligned}
3 \log [\% \mathrm{Si}]+4 \log [\% \mathrm{~N}]= & -\frac{15541.6}{T}-37.432 \\
& +14.732 \log T \\
& -\frac{436}{T}[\% \mathrm{~N}]
\end{aligned}
$$

Si concentration in $\gamma$ - $\mathrm{Fe}$ was considered equal to the concentration in $\alpha$ solid solution for the reason presented above that the effect of $\mathrm{Si}$ solubility on the thermodynamic properties of both crystalline structures is virtually the same [19]. At $1273 \mathrm{~K}$, equation (11) becomes:

$$
\log [\% \mathrm{Si}]=-1.300-1.333 \log [\% \mathrm{~N}]-0.114[\% \mathrm{~N}]
$$

By assuming Henry's law, equation (1), the equation of the solubility constant $K_{\mathrm{I}}$ for $\mathrm{Si}_{3} \mathrm{~N}_{4}$ dissolution in $\gamma$-Fe, equation (3) in Table 2 expands to:

$$
\begin{aligned}
\log K_{\mathrm{I}}= & 3 \log [\% \mathrm{Si}]+4 \log [\% \mathrm{~N}] \\
& +3\left(e_{\mathrm{Si}}^{\mathrm{Si}}[\% \mathrm{Si}]+e_{\mathrm{Si}}^{\mathrm{N}}[\% \mathrm{~N}]\right) \\
& +4\left(e_{\mathrm{N}}^{\mathrm{N}}[\% \mathrm{~N}]+e_{\mathrm{N}}^{\mathrm{Si}}[\% \mathrm{Si}]\right)
\end{aligned}
$$

Rearranging equation (13) with equation (11) and $e_{\mathrm{Si}}^{\mathrm{Si}}, e_{\mathrm{N}}^{\mathrm{Si}}, e_{\mathrm{N}}^{\mathrm{N}}$ and $e_{\mathrm{Si}}^{\mathrm{N}}$ in Table 3 gives:

$$
\begin{aligned}
\log K_{\mathrm{I}}= & -\frac{15541.6}{T}-37.432 \\
& +14.732 \log T \\
& +\left(\frac{2188}{T}-0.845\right)[\% \mathrm{Si}] \\
& +\left(\frac{1644}{T}-0.672\right)[\% \mathrm{~N}]
\end{aligned}
$$

which is the equation for the solubility constant of silicon nitride dissolution in pure $\gamma$-Fe. The range

Table 4. Temperature dependence of the $\mathrm{Si}$ and $\mathrm{N}$ concentration in ferritic and austenitic iron [16]

\begin{tabular}{cc} 
Chemical equilibrium & Equation \\
\hline $\log [\% \mathrm{~N}]_{\alpha}=-\frac{1606}{T}-3.511+\frac{1}{2} \log P_{\mathrm{N}_{2}}$ & $(8)$ \\
$\log [\% \mathrm{~N}]=\frac{2833.6}{T}-17.719+3.683 \log T-\frac{109}{T}[\% \mathrm{~N}]+\frac{1}{2} \log P_{\mathrm{N}_{2}}$ & $(9)$ \\
$\log \left([\% \mathrm{Si}]_{\alpha}^{3}[\% \mathrm{~N}]_{\alpha}^{4}\right]=-\frac{33300}{T}+19.4$ & $(10)$ \\
\hline
\end{tabular}

Note: $[\% \mathrm{i}]_{x}$ and $[\% \mathrm{i}]$ are the concentrations by weight percent of $i$ element in ferrite and austenite, respectively. 
of solubility measurements used to derive equations (8)-(10) was $0.48<[\% \mathrm{Si}]<0.75$ [16]. For the mean silicon concentration of $[\% \mathrm{Si}]=0.61 \%$ and the resulting value of $[\% \mathrm{~N}]=0.15$ by equation (12), equation (14) gives $\log K_{\mathrm{I}}=-3.27$ at $1273 \mathrm{~K}$.

\section{3. $\mathrm{Si}_{3} \mathrm{~N}_{4}$ dissolution in chromium alloyed steels}

The interaction of chromium with nitrogen from the $\mathrm{Si}_{3} \mathrm{~N}_{4}$ ceramic tool is very strong for a chromium alloyed steel and $\mathrm{CrN}$ precipitates in $\gamma$-Fe phase for concentrations well below $13 \mathrm{wt} \% \mathrm{Cr}$ at $1273 \mathrm{~K}$ [23]. Equation (4) in Table 1 must be added to the solubility [equation (3)] of the ceramic, leading to global equation (5).

The equilibrium constant $K_{I I}$ depends on the $\mathrm{Cr}$ and $\mathrm{N}$ concentrations in $\gamma-\mathrm{Fe}$ and on the interaction coefficients, equation (1) as follows:

$$
\begin{aligned}
\log K_{\mathrm{II}}= & -\log [\% \mathrm{Cr}]-\log [\% \mathrm{~N}] \\
& -\left(e_{\mathrm{Cr}}^{\mathrm{Cr}}[\% \mathrm{Cr}]+e_{\mathrm{Cr}}^{\mathrm{N}}[\% \mathrm{~N}]\right) \\
& -\left(e_{\mathrm{N}}^{\mathrm{N}}[\% \mathrm{~N}]+e_{\mathrm{N}}^{\mathrm{Cr}}[\% \mathrm{Cr}]\right)
\end{aligned}
$$

Using equation (2) to express $e_{\mathrm{N}}^{\mathrm{Cr}}$ as a function of $e_{\mathrm{Cr}}^{\mathrm{N}}$ and replacing $e_{\mathrm{Cr}}^{\mathrm{Cr}}$ and $e_{\mathrm{N}}^{\mathrm{N}}$ by their respective values at $1273 \mathrm{~K}$, Table 3 , equation (15) is rearranged to:

$$
\begin{aligned}
\log [\% \mathrm{Cr}]+\log [\% \mathrm{~N}] & +0.086[\% \mathrm{~N}]-0.0032[\% \mathrm{Cr}] \\
= & -\log K_{\mathrm{II}}-([\% \mathrm{~N}] \\
& +0.2692[\% \mathrm{Cr}]) e_{\mathrm{Cr}}^{\mathrm{N}}
\end{aligned}
$$

The values of $\log K_{\mathrm{II}}$ and $e_{\mathrm{Cr}}^{\mathrm{N}}$ are obtained by lineal regression analysis from the $[\% \mathrm{Cr}]$ and $[\% \mathrm{~N}]$ values at the solubility limit line of $\mathrm{CrN}$ in $\gamma$-Fe field of the $\mathrm{Fe}-\mathrm{Cr} \mathrm{N}$ phase diagram at $1273 \mathrm{~K}$ [23]. The first member of equation (16) is plotted against $([\% \mathrm{~N}]+0.2692[\% \mathrm{Cr}])$ as shown in Fig. 2, giving the values of $K_{\mathrm{II}}=0.86$ and $e_{\mathrm{Cr}}^{\mathrm{N}}=-0.40$.

From the chemical equilibria I, II and III in Table 1, and the above values of $K_{\mathrm{I}}$ and $K_{\mathrm{II}}$ at $1273 \mathrm{~K}$,

$$
\log K_{\mathrm{III}}-\log K_{\mathrm{I}}+4 \log K_{\mathrm{II}}-0.17
$$

On the other hand, $\log K_{\text {III }}$ can be written as:

$$
\begin{aligned}
\log K_{\mathrm{III}}= & 3 \log [\% \mathrm{Si}]-4 \log [\% \mathrm{Cr}] \\
& +3\left(e_{\mathrm{Si}}^{\mathrm{Si}}[\% \mathrm{Si}]+e_{\mathrm{Si}}^{\mathrm{N}}[\% \mathrm{~N}]\right. \\
& \left.+e_{\mathrm{Si}}^{\mathrm{C}}[\% \mathrm{C}]+e_{\mathrm{Si}}^{\mathrm{Cr}}[\% \mathrm{Cr}]\right) \\
& -4\left(e_{\mathrm{Cr}}^{\mathrm{Cr}}[\% \mathrm{Cr}]+e_{\mathrm{Cr}}^{\mathrm{N}}[\% \mathrm{~N}]\right. \\
& \left.+e_{\mathrm{Cr}}^{\mathrm{C}}[\% \mathrm{C}]+e_{\mathrm{Cr}}^{\mathrm{Si}}[\% \mathrm{Si}]\right)
\end{aligned}
$$

Replacing all the known parameters in equation (18), the general equation for $\mathrm{Si}$ and $\mathrm{N}$ solubilities in the $\gamma$ phase of chromium alloyed steels thus becomes:

$$
\begin{aligned}
{[\% \mathrm{~N}]=} & 0.076-1.35 \log [\% \mathrm{Si}] \\
& -0.20[\% \mathrm{Si}]+1.79 \log [\% \mathrm{Cr}] \\
& -0.74[\% \mathrm{C}]
\end{aligned}
$$

The carbon and chromium content in the first chromium alloyed steel in Table 5, the DIN 1.2080 tool steel, are above the solubility limit in $\gamma$-Fe at $1273 \mathrm{~K}$, while these same alloying elements are fully dissolved in the DIN 1.4021 steel at the reference temperature [24]. The saturation contents of carbon and chromium in $\gamma$-Fe at $1273 \mathrm{~K}$ for the $2.0 \mathrm{wt} \% \mathrm{C}$,

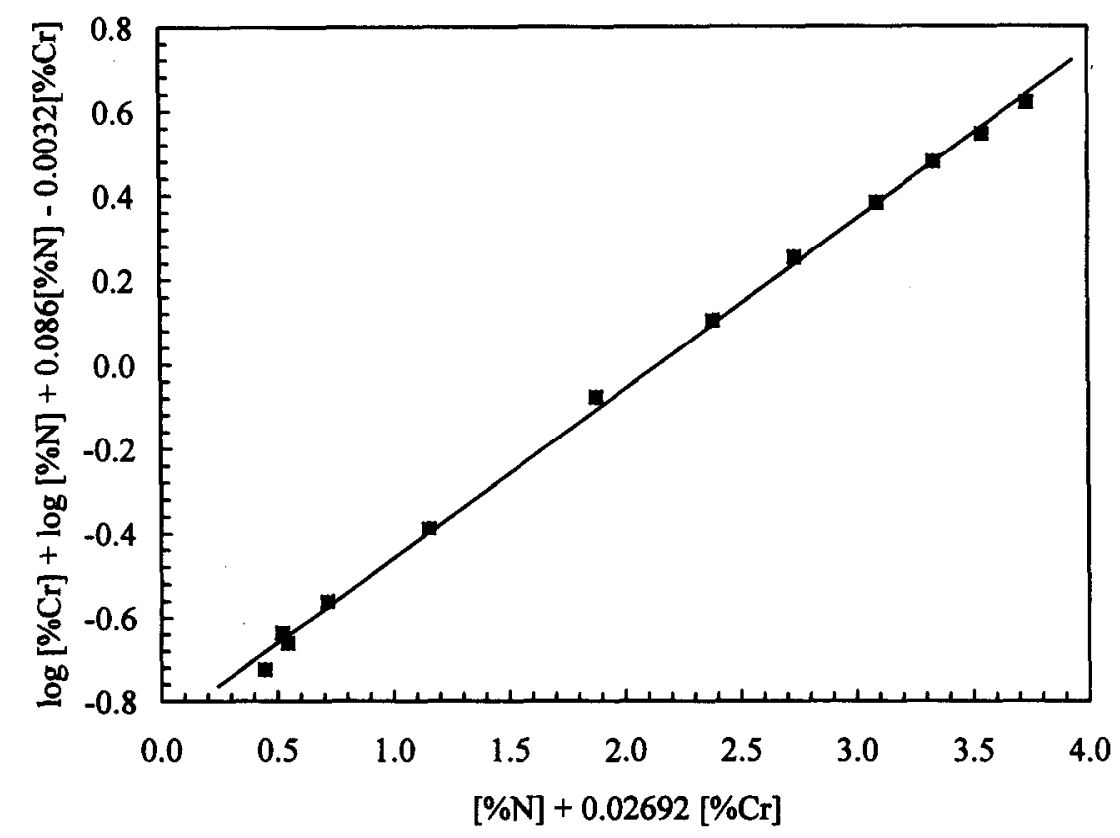

Fig. 2. Graphical determination of $e_{\mathrm{Cr}}^{\mathrm{N}}$ and solubility constant $K_{\mathrm{II}}$ by equation (16). 
Table 5. Si, $\mathrm{N}$ and $\mathrm{Si}_{3} \mathrm{~N}_{4}$ equilibrium solubilities in the metal chip and crater wear parameter $x$

\begin{tabular}{|c|c|c|c|c|c|}
\hline Metal & Si $(w t \%)$ & $N(w t \%)$ & $\mathrm{Si}_{3} \mathrm{~N}_{4}\left(\mathrm{~cm}^{3} / \mathrm{mol} \mathrm{Fe}\right)$ & $\begin{array}{c}\text { Relative } \mathrm{Si}_{3} \mathrm{~N}_{4} \\
\text { solubility }\end{array}$ & $\kappa$ \\
\hline Pure iron & 0.34 & 0.23 & 0.10 & 26 & - \\
\hline $2 \mathrm{wt} \% \mathrm{C}, 12 \mathrm{wt} \% \mathrm{Cr}$ steel (DIN 1.2080$)$ & 0.80 & 0.53 & 0.23 & 59 & $9.4 \times 10^{-5 a}, 2.6 \times 10^{-6 b}$ \\
\hline $0.2 \mathrm{wt} \% \mathrm{C}, 13 \mathrm{wt} \% \mathrm{Cr}$ steel (DIN 1.4021 ) & 1.82 & 1.21 & 0.53 & 136 & - \\
\hline $3.9 \mathrm{wt} \% \mathrm{C}, 2.9 \mathrm{wt} \% \mathrm{Si}$ gray cast iron & 0.014 & 0.009 & 0.0039 & 1 & $1.1 \times 10^{-7 \mathrm{a}}$ \\
\hline $0.42 \mathrm{wt} \% \mathrm{C}$ carbon steel (DIN 1.1186 ) & 0.32 & 0.21 & 0.093 & 24 & $1.6 \times 10^{-6 \mathrm{c}}, 8.2 \times 10^{-7 \mathrm{c}}$ \\
\hline
\end{tabular}

${ }^{\mathrm{a}} \mathrm{Si}_{3} \mathrm{~N}_{4} \mathrm{CeO}_{2}$ ceramic tool [5].

${ }^{\mathrm{b}} \mathrm{Si}_{3} \mathrm{~N}_{4}-\mathrm{AlN}-\mathrm{CeO}_{2}$ ceramic tool [5].

${ }^{c} \mathrm{Commercial}$ silicon nitride inserts [6].

$12 \mathrm{wt} \% \mathrm{Cr}$ steel were determined from the isothermal section of the $\mathrm{Fe}-\mathrm{Cr}-\mathrm{C}$ phase diagram at $1273 \mathrm{~K}$ [24]. For the approximate saturation values of $[\% \mathrm{C}]=0.9$ and $[\% \mathrm{Cr}]=4.4$ the final relationship between the concentrations of $\mathrm{Si}$ and $\mathrm{N}$ in $\gamma-\mathrm{Fe}$ for the DIN 1.2080 tool steel becomes:

$$
[\% \mathrm{~N}]=0.56-1.35 \log [\% \mathrm{Si}]-0.20[\% \mathrm{Si}]
$$

For a $0.2 \mathrm{wt} \% \mathrm{C}, 13 \mathrm{wt} \% \mathrm{Cr}$ steel, the isothermal section of the $\mathrm{Fe}-\mathrm{Cr}-\mathrm{C}$ phase diagram at $1273 \mathrm{~K}$ shows that all the carbon and chromium are dissolved in $\gamma-\mathrm{Fe}$ [24]. By straightforward replacing the nominal $[\% \mathrm{C}]$ and $[\% \mathrm{Cr}]$ values of the alloy in equation (19), yields

$$
[\% \mathrm{~N}]=1.92-1.35 \log [\% \mathrm{Si}]-0.20[\% \mathrm{Si}]
$$

\section{4. $\mathrm{Si}_{3} \mathrm{~N}_{4}$ dissolution in grey cast iron and carbon steels}

The solubility constant, $K_{1}$, for the dissolution of silicon nitride in $\gamma$-Fe phase of grey cast iron and carbon steels can be expressed by equation (13) with addition of the first order interaction coefficients of carbon on silicon and nitrogen, in due proportions. Replacing $K_{\mathrm{I}}$ for its value at $1273 \mathrm{~K}$ $\left(K_{\mathrm{I}}=-3.27\right), e_{\mathrm{Si}}^{\mathrm{C}}$ and $e_{\mathrm{N}}^{\mathrm{C}}$ for the values given in Table 3 , the final equation is obtained:

$$
\begin{aligned}
\log [\% \mathrm{Si}]+0.3[\% \mathrm{Si}]= & -1.09-1.333 \log [\% \mathrm{~N}] \\
& -0.325[\% \mathrm{~N}]-0.33[\% \mathrm{C}]
\end{aligned}
$$

As before, grey cast iron represents an alloy where the alloying elements exceed the solubility limit in $\gamma$-Fe, while they are fully dissolved in carbon steels. The saturation solubilities for carbon and silicon in $\gamma$-Fe at $1273 \mathrm{~K}$ were graphically determined from an isothermal section of the $\mathrm{Fe}-\mathrm{Si}-\mathrm{C}$ phase diagram at $1273 \mathrm{~K}$ [24]. The approximate value of $[\% \mathrm{C}]=1.0$ was found for the nominal Si content of the grey cast iron composition in Table 5 $([\% \mathrm{Si}]=2.9)$. The remaining carbon precipitates as graphite. The elements $\mathrm{Mn}$ and $\mathrm{S}$ of the cast iron composition precipitate as $\mathrm{MnS}$ and should not interfere with the equilibria set in Table 1. By replacing these values of $[\% \mathrm{C}]$ and $[\% \mathrm{Si}]$ in equation (22), the calculated value of the solubility of $\mathrm{N}$ in $\gamma-\mathrm{Fe}$ phase of grey cast iron becomes $[\% \mathrm{~N}]=0.009$.

The silicon and nitrogen solubilities in carbon steels can be calculated by replacing the carbon content $[\% \mathrm{C}]$ in equation (22). For a $0.42 \mathrm{wt} \% \mathrm{C}$ carbon steel, Table 5, this relationship is thus:

$$
\begin{aligned}
\log [\% \mathrm{Si}]+0.3[\% \mathrm{Si}]= & -1.229-1.333 \log [\% \mathrm{~N}] \\
& -0.325[\% \mathrm{~N}]
\end{aligned}
$$

\section{DISCUSSION}

The results of the precedent section can lead to the estimation of the chemical wear of silicon nitride in contact with ferrous alloys. The $\mathrm{Si}$ and $\mathrm{N}$ saturation in the metal chip is given by equations (12), (20), (21) and (23) for pure iron and for chromium alloyed and carbon steels, respectively. The relationship between $\mathrm{Si}$ and $\mathrm{N}$ equilibrium concentration for each alloy is plotted in Fig. 3, together with the point representative of the nitrogen solubility in the gray cast iron as calculated in Section 2.4. The concentrations of $\mathrm{Si}$ and $\mathrm{N}$ in iron in equilibrium with the $\mathrm{Si}$ and $\mathrm{N}$ source, the $\mathrm{Si}_{3} \mathrm{~N}_{4}$ ceramic, is given by the interception points of the saturation curves with the straight line representing the stoichiometric $\mathrm{Si}_{3} \mathrm{~N}_{4}$ composition. The resulting solubility values span into a range of two orders of magnitude showing that the composition of the ferrous alloy strongly affects the wear resistance of the silicon nitride cutting tools.

Table 5 gives the equilibrium solubilities of $\mathrm{Si}, \mathrm{N}$ and the concentration of dissolved $\mathrm{Si}_{3} \mathrm{~N}_{4}$ in equilibrium with the selected alloys at $1273 \mathrm{~K}$ as well as the values of the crater wear parameter $\kappa$ obtained in a previous work for DIN 1.2080 tool steel and gray cast machining [5] and from literature, for $0.42 \mathrm{wt} \% \mathrm{C}$ carbon steel turning [6]. $\kappa$ is defined as $\kappa=\Gamma / M$, the ratio between the crater wear rate, ( $\Gamma=\mathrm{KM} \cdot \mathrm{KT} / t ; \mathbf{K M}$ being the distance between the tool edge and crater center, KT the crater depth and $t$ the cutting time) and the metal removal rate ( $M=$ cutting speed $\times$ feed) [5]. The $\mathrm{Si}_{3} \mathrm{~N}_{4}$ solubility is normalized to the lowest value, the value in the gray cast iron in Table 5. It becomes evident that additions of $\mathrm{C}$ or $\mathrm{Si}$ to the $\mathrm{Fe}$ alloy decrease $\mathrm{Si}_{3} \mathrm{~N}_{4}$ 


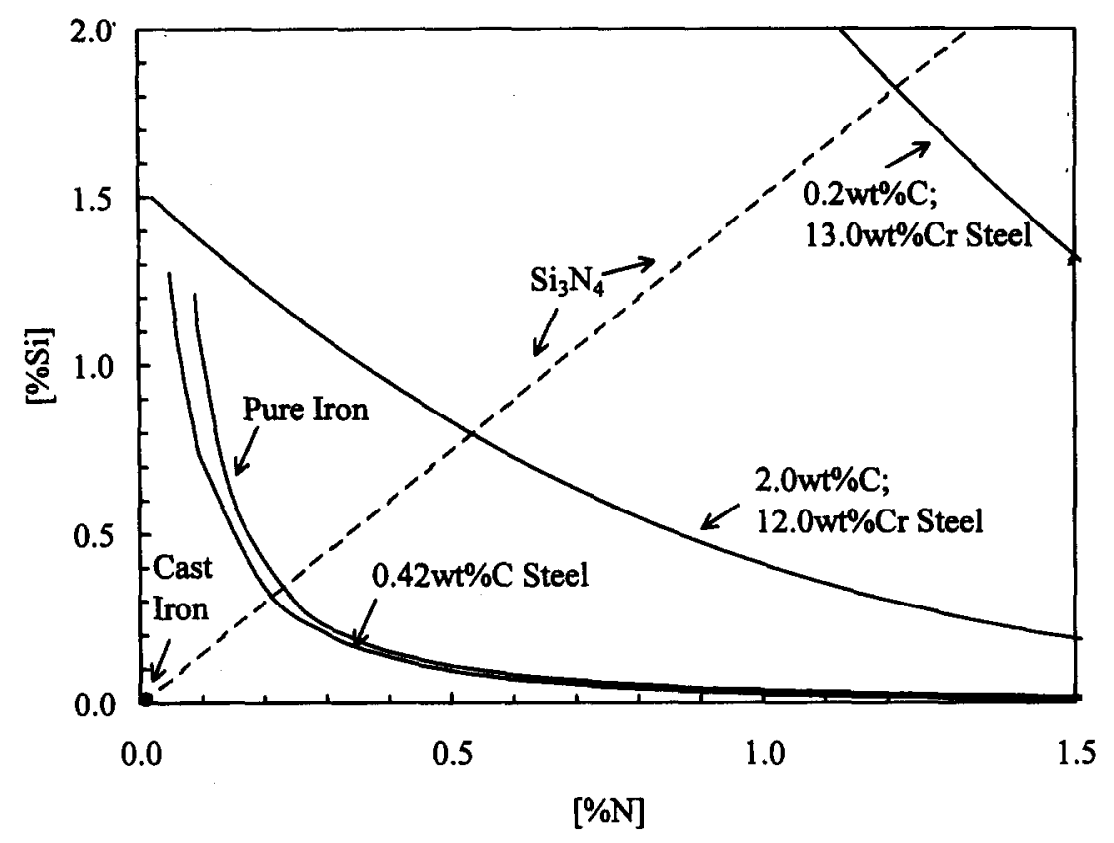

Fig. 3. Equilibrium solubility lines of $\mathrm{Si}$ and $\mathrm{N}$ in $\gamma$-Fe at $1273 \mathrm{~K}$ for distinct iron alloys.

solubility, the alloying with $\mathrm{Cr}$ having the opposite effect. These results corroborate the observations that silicon nitride tools present the highest resistance to wear by dissolution when machining gray cast iron $[1,4,5,13]$ as given by the low value of $\kappa$. In Fig. 4 the wear parameter $\kappa$ is plotted against $\mathrm{Si}_{3} \mathrm{~N}_{4}$ solubility in a $\log -\log$ scale, resulting in a straight line of slope unity, the two variables being directly proportional. The scatter of crater wear parameter $\kappa$ for each type of alloy in Fig. 4 are mostly due to differences of secondary phases used as sintering aids of the silicon nitride insert materials [5], Table 5. It is thus possible to predict relative wear rates of $\mathrm{Si}_{3} \mathrm{~N}_{4}$ cutting tools when machining different ferrous alloys using the chemical wear model.

Although other models $[1,7,10,11,14,15]$ were developed to predict relative wear rates of ceramic cutting tools based on thermodynamics, there are some important differences with respect to the pre-

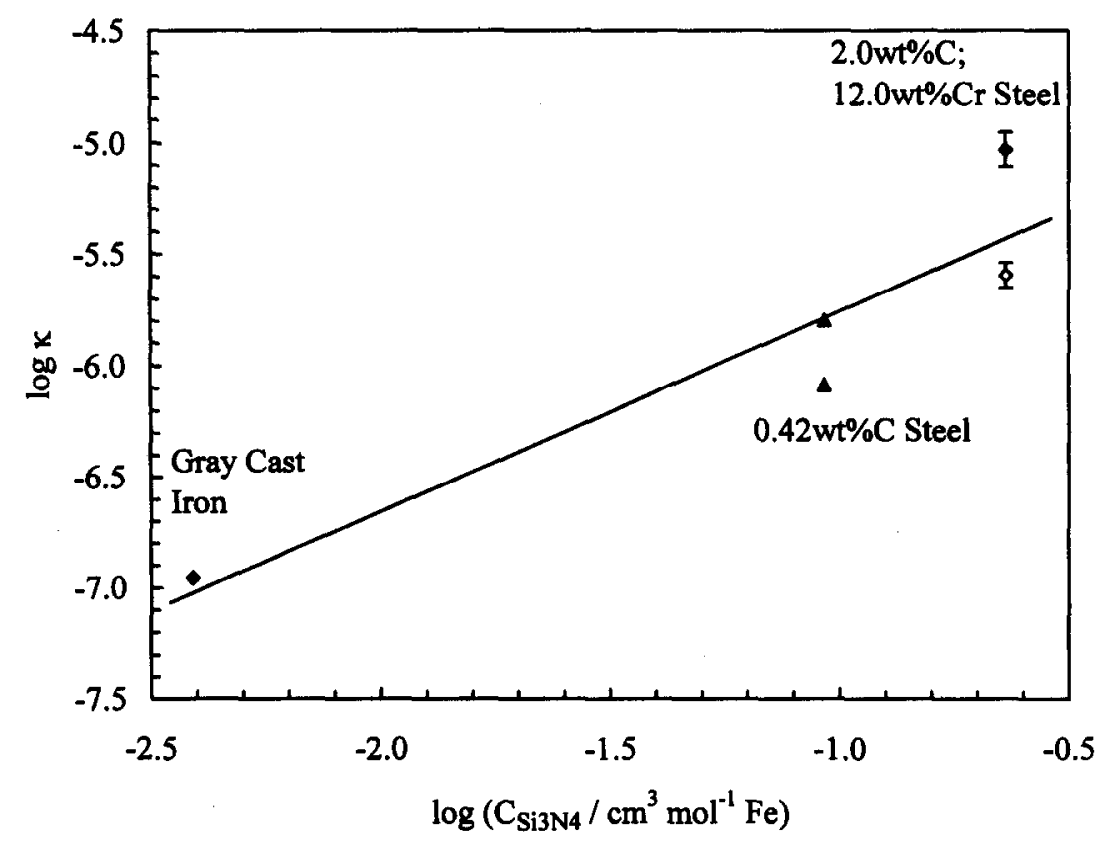

Fig. 4. Relationship between crater wear parameter $\kappa$ and $\mathrm{Si}_{3} \mathrm{~N}_{4}$ solubility in $\gamma$-Fe. $\left(\bullet\right.$, 口) $\mathrm{Si}_{3} \mathrm{~N}_{4}-\mathrm{CeO}_{2}$ ceramic tool [5]; (O) $\mathrm{Si}_{3} \mathrm{~N}_{4}-\mathrm{AlN}-\mathrm{CeO}_{2}$ ceramic tool [5]; (A) commercial silicon nitride inserts [6]. 
sent model that are highlighted. The early studies of Kramer et al. $[10,11]$ have only considered tool wear by solution in pure $\alpha-\mathrm{Fe}$ and postulated that the $\alpha-\mathrm{Fe}$ is preserved in the metastable form at the high temperatures developed during cutting. Since seizure conditions occur at the contact between the chip and the tool rake face $[5,25]$, the equilibrium structure, $\gamma-\mathrm{Fe}$, is used in the present study for the calculation of solubilities. It should be pointed out that the results of static ceramic/metal interaction diffusion couples are often performed above $1273 \mathrm{~K}$, where no doubts exist about the $\alpha / \gamma-\mathrm{Fe}$ transformation. The reactivity of the diffusion couples was tentatively correlated to chemical wear in turning by using Kramer's model $[1,7]$.

The $\mathrm{Si}_{3} \mathrm{~N}_{4}$ solubility in pure iron calculated by the model of Kramer has a value of $0.74 \mathrm{~cm}^{3} / \mathrm{mol}$ $\mathrm{Fe}$ [10] which is much higher than the value in Table 5. The discrepancy cannot be attributed to differences of the iron crystalline structures adopted in the two models bccausc a calculation made with the solubility constant as experimentally determined in $\alpha$-Fe, yields a value of $0.04 \mathrm{~cm}^{3} / \mathrm{mol} \mathrm{Fe}$ [16]. In the model of Kramer the relative partial molar excess free energies of $\mathrm{Si}$ and $\mathrm{N}$ were estimated at $1600 \mathrm{~K}$, for a $\mathrm{Fc}-19$ at $\% \mathrm{Si}$ alloy in equilibrium with liquid iron and $\mathrm{N}_{2}$ gas saturated iron, respectively. These values were later used irrespectively of the actual values of $S i$ and $N$ concentrations and of temperature [7]. Furthermore, self interaction coefficients arc only implicit in those procedures, such approximations giving rise to large uncertainties in any final quantitative result. Vleugels et al. introduced interaction coefficients to distinguish the chemical reactivity of sialon ceramics with several iron alloys $[7,14,15]$. The thickness of the reacted layer in metal/sialon static couples correlates in a non straightforward way to the calculated nitrogen solubilities [15]. However these values of nitrogen solubility have not considered $\mathrm{Si}$ solution from $\mathrm{Si}_{3} \mathrm{~N}_{4}$ and its effect on $\mathrm{N}$ solubility, a level of correction that can only be achieved if all of the most intensive crossed interactions are taken into account as in Table 3.

\section{CONCLUSIONS}

The values of the first order interaction coefficients of $\mathrm{N}, \mathrm{Si}$ and alloying elements in $\gamma$-re were reviewed. It is shown that the first order interaction coefficients of dissolving and alloying elements on $\mathrm{N}, \mathrm{Si}, \mathrm{C}$ and $\mathrm{Cr}$ in the austenitic phase bear additional contributions to the $\mathrm{Si}_{3} \mathrm{~N}_{4}$ solubility in the iron alloys which happen to be as strong as those of the elements on the $\mathrm{N}$ alone.

The results of the present thermodynamic model were able to predict relative wear rates of silicon nitride base inserts in the machining of iron alloys.
This thermodynamic tool also allows the calculation of $\mathrm{Si}_{3} \mathrm{~N}_{4}$ solubility lines in iron alloys phase diagrams. The concept can be adopted to alloying elements other than $\mathrm{Si}, \mathrm{N}, \mathrm{C}$ and $\mathrm{Cr}$. This method is restricted so far to $\mathrm{Si}_{3} \mathrm{~N}_{4}$ but it can be extended to sialons, composites or even to other ceramic materials giving a more consistent approach than those reported.

Acknowledgements-The financial support from JNICT under the research contract PBIC/C/CTM/1917/95 is gratefully acknowledged. F. J. O. acknowledges the financial support of the Sub-Programa Ciência e Tecnologia do 2* Quadro Comunitário de Apoio.

\section{REFERENCES}

1. Buljan, S. T. and Wayne, S. F., Wear, 1989, 133, 309.

2. Buljan, S. T. and Wayne, S. F., Adv. Ceram. Mater., $1987,2,813$.

3. Baldoni, J. G. and Buljan, S. T., Ceram. Bull, 1988, 67,381 .

4. Tönshoff, H. K. and Bartsch, S., Can. Metall. Q., 1989, 28, 353.

5. Silva, R. F., Gomes, J. M., Miranda, A. S. and Vieira, J. M., Wear, 1991, 148, 69.

6. Yeomans, J. A., Ph.D. Thesis, University of Cambridge, Cambridge, 1986.

7. Vleugels, J., Jacobs, P., Kruth, J. P., Vanherck, P., Du Mong, W. and Van Der Biest, O., Wear, 1995, 189, 32.

8. Lo Casto, S., Lo Valvo, E., Ruisi, V. F., Lucchini, E. and Maschio, S., Wear, 1993, 160, 227.

9. Kannatey-Asibu, E., J. Manufact. Syst., 1990, 9, 159.

10. Kramer, B. M. and Suh, N. P., J. Eng. Ind., 1980, $102,303$.

11. Kramer, B. M. and Judd, P. K., J. Vac. Sci. Technol. $A, 1985,3,2439$.

12. Aronsson, B., Powder Metall. and Related High Temperature Materials, Bombay, India, 14-17 December 1983, p. 319.

13. Blackman, T. N., The Foundryman, January 1990 , p. 17.

14. Vleugels, J. and Van Der Biest, O., Third EuroCeramics, Vol. 1, ed. P. Duran and J. F. Fernandez, Faenza Editrice Ibérica S. L., Spain, 1993, p. 1121.

15. Vleugels, J., Vandeperre, L. and Van Der Biest, O., $J$. Mater. Res., 1996, 11, 1265.

16. Kunze, J., Pungun, O. and Friedrich, K., J. Mater. Sci. Lett., 1986, 5, 815 .

17. Parker, R. H., An Introduction to Chemical Metallurgy. Pergamon Press, Oxford, 1978.

18. Lupis, C. H. P., Chemical Thermodynamics of Materials. North-Holland, New York, 1983.

19. Hansen, M., Constitution of Binary Alloys, 2nd Edn. McGraw-Hill, New York, 1958.

20. Fujisawa, T., Kimura, S. and Sakao, H., Tetsu To Hagane, 1981, 67, 940.

21. Sigworth, G. K. and Elliot, J. F., Metal Sci., 1974, 8, 298.

22. Kagawa, A., Okamoto, T. and Goda, S., J. Mater. Sci., 1988, 23, 649 .

23. Hertzman, S. and Jarl, M., Metall. Trans. A, 1987 , 18A, 1745.

24. Metals Handbook Vol. 3, American Society for Metals, Metals Park, OH, 1992.

25. Trent, E. M., Metal Cutting. Butterworths, Guildford, 1984. 